\title{
Cerithiidae, Litiopidae, Modulidae and Planaxidae (Gastropoda, Cerithioidea) collected by the Marion Dufresne MD55 expedition in southeastern Brazil
}

\author{
Daniel Caracanhas Cavallari ; Sérgio Mendonça Almeida² \& Luiz Ricardo L. Simone ${ }^{3}$ \\ 1 Universidade de São Paulo (USP), Faculdade de Filosofia, Ciências e Letras de Ribeirão Preto (FFCLRP), Departamento de Biologia (DB). \\ Ribeirão Preto, SP, Brasil. \\ ORCID: http://orcid.org/0000-0003-3104-6434. E-mail: dccavallari@gmail.com (corresponding author) \\ 2 Universidade Católica de Pernambuco (UNICAP), Centro de Ciências da Saúde, Laboratório de Zoologia. Recife, PE, Brasil. \\ ORCID: http://orcid.org/0000-0002-1336-6525. E-mail: smalmeidasj@gmail.com \\ ${ }^{3}$ Universidade de São Paulo (USP), Museu de Zoologia (MZUSP). São Paulo, SP, Brasil. \\ ORCID: http://orcid.org/0000-0002-1397-9823. E-mail: Irsimone@usp.br
}

\begin{abstract}
Several deep-water mollusks collected during the Marion Dufresne MD55 expedition off SE Brazil have been studied in recent papers. The present work focuses on eight species belonging to the cerithioidean families Cerithiidae, Litiopidae, Modulidae and Planaxidae. Three species have their geographic distributions greatly expanded: Bayericerithium bayeri Petuch, 2001 from Pernambuco to Rio Grande do Norte and Ceará states (north) and to Bahia and Espírito Santo states (south), Brazilian coast; Ittibittium oryza (Mörch, 1876), from the Caribbean to the SW Atlantic; and Angiola lineata (Costa, 1778), from Trindade Island, Brazil to the Abrolhos Slope, nearly $870 \mathrm{~km}$ westward. Four species reported herein had their bathymetric ranges greatly expanded: Alaba incerta (d'Orbigny, 1841) from 0-40 m to $300 \mathrm{~m}$; B. bayeri from 0-2 $\mathrm{m}$ to $120 \mathrm{~m}$ (live specimens); Litiopa melanostoma Rang, 1829 from 0-805 m to 1,550 m; Fossarus orbignyi Fischer, 1864 from 0-40 to $830 \mathrm{~m}$ (shells only).
\end{abstract}

Key-Words. Bayericerithium bayeri; Deep-water mollusks; Ittibittium oryza; New records; Range extension.

\section{INTRODUCTION}

The MD55 cruise of R/V Marion Dufresne took place in May and June 1987 as a joint project of the Muséum national d'histoire naturelle (MNHN; Paris, France) and Universidade Santa Úrsula (USU; Rio de Janeiro, Brazil) (Tavares, 1999). The expedition recovered numerous deep-water mollusks from the southeastern Brazilian coast. Most of this material remained unstudied for years, but recent efforts have been steadily changing this scenario, e.g., comprehensive reports on Triphorinae (Fernandes et al., 2013), Naticidae (Simone, 2014), Fissurellidae (Simone \& Cunha, 2014), Seguenziidae (Salvador et al., 2014), and Calliostomatidae (Cavallari et al., 2019). The present work focuses on a small assembly of species belonging to the cerithioidean families Cerithiidae, Litiopidae, Modulidae and Planaxidae.

Cerithiidae is the largest family within Cerithioidea. It includes nearly two hundred spe- cies of small to medium-sized $(10-114 \mathrm{~mm}$ shell length) marine snails occurring in tropical and subtropical shallow waters around the globe, with a few deep-water representatives (e.g., species in the genera Varicopeza Gründel, 1976 and Argyropeza Melvill \& Standen, 1901; Beesley, Ross \& Wells, 1998; Strong et al., 2011). Only three genera and five cerithiid species have been recorded in Brazilian waters: Bayericerithium bayeri Petuch, 2001, Bittiolum varium (Pfeiffer, 1840), Cerithium attratum (Born, 1778), C. eburneum Bruguière, 1792 and C. litteratum (Born, 1778) (Rios, 1994; Petuch, 2001; Rios, 2009; Rosenberg, 2009).

Litiopids are considerably less diverse if compared to cerithiids and planaxids, with a total number of species estimated at 16-18 (Strong et al., 2011). Nevertheless, they are a widely distributed group of small-sized sea snails (less than $25 \mathrm{~mm}$ in length) that occur among algal and seagrass fronds in shallow, warm-temperate and tropical seas (Houbrick, 1987a; Beesley, Ross \& 
Wells, 1998; Strong et al., 2011). Two species have been recorded in the Western Atlantic to date, Alaba incerta (d'Orbigny, 1841) and Litiopa melanostoma Rang, 1829 (Rios, 2009; Rosenberg, 2009).

Modulids are an even less diverse group encompassing six extant (Houbrick, 1980; Strong et al., 2011) small, shallow-water species. Their distribution is restricted to tropical and subtropical regions, and Modulus modulus (Linnaeus, 1758), M. bayeri Petuch, 2001, and Trochomodulus carchedonius (Lamarck, 1822) are the only species recorded in Brazilian waters (Rosenberg, 2009).

The Planaxidae are a family of largely marine, tropical to subtropical snails, usually inhabiting rocky shores. Remarkably, they brood eggs in a special head-foot concavity (Simone, 2001). With a total number of valid species estimated at 30-40 (Strong et al., 2011), planaxids are represented in Brazil by two species: Angiola lineata (Costa, 1778) and Fossarus orbignyi Fischer, 1864 (Rios, 2009).

Herein we provide updated taxonomic information on eight species belonging to the above-mentioned families. We report new records from the MD55 expedition, some of which are complementary to previous works (e.g., Leal, 1991) and represent relevant geographic and bathymetric range extensions.

\section{MATERIAL AND METHODS}

The MD55 specimens studied herein consist of shells from the collections of the Muséum national d'histoire naturelle (MNHN) and Museu de Zoologia da Universidade de São Paulo (MZSP), Brazil. Additional material from the Academy of Natural Sciences of Drexel University (ANSP), Philadelphia, USA, was also analyzed. The malacologists onboard of the R/V Marion DuFresne, namely Philippe Bouchet, José $\mathrm{H}$. Leal and Bernard Métivier, recovered the above-mentioned MD55 specimens among the extensive material collected by the expedition. Sampling methods employed included Blake and Beam trawls, a Charcot dredge, and a Box corer at 67 stations along the continental platform of Rio de Janeiro and the VitóriaTrindade Seamount Chain (for detailed information, see Tavares, 1999). Examined material lists are given in each species entry. Photographs and measurements were obtained using a Zeiss AxioCam MRc 5 and Zeiss AxioVision SE64 Rel 4.8 imaging software. Unless otherwise stated, only MD55 specimens were measured. The following abbreviations are used throughout the text for shell measurements: $H$, shell height; $W$, shell width; $h$, aperture height; $w$, aperture width.

\section{SYSTEMATICS}

\section{Family Cerithiidae Genus Ittibittium Houbrick, 1993}

Type species: Ittibittium parcum Gould, 1861, by original designation; Recent, Indo-Pacific.

\section{Ittibittium oryza (Mörch, 1876)}

(Figs. 1-6)

Synonymy see Faber (2005: 82). Complement:

"Bittium" turriculum: Redfern, 2001: 21, figs. 88A, 88B (non Usticke, 1969).

\section{Type locality: Saint Thomas.}

Distribution: Caribbean, from the Bahamas and Greater Antilles to Santa Lucia (Faber, 2005).

New occurrence: Southwestern Atlantic, Brazil, off Espírito Santo.

Material examined: Brazil; off Espírito Santo: Abrolhos Continental Slope, $18^{\circ} 50^{\prime} \mathrm{S}, 37^{\circ} 57^{\prime} \mathrm{W}, 60 \mathrm{~m}, \mathrm{MNHN}$, 1 shell (MD55, sta. DC83, 28/v/1987); Jaseur Seamount, $20^{\circ} 27^{\prime} \mathrm{S}, 35^{\circ} 54^{\prime} \mathrm{W}, 54 \mathrm{~m}, \mathrm{MNHN}, 2$ shells (MD55, sta. DC34; 15/v/1987); Victoria Bank, 20³2'S, 38 $10^{\prime} \mathrm{W}, 52 \mathrm{~m}$, MZSP 122161, 5 shells (MD55, sta. DC22, 13/v/1987);

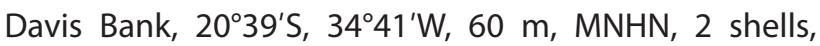
MZSP 147431, 1 shell (MD55, sta. DC40, 17/v/1987); Jaseur Seamount, eastern summit, $20^{\circ} 42^{\prime} \mathrm{S}, 35^{\circ} 22^{\prime} \mathrm{W}$, 15-82 m, 1 shell (MD55, sta. DC35, 17/v/1987; among coral sand); Dogaressa Bank, 20 $50^{\prime} \mathrm{S}, 34^{\circ} 44^{\prime} \mathrm{W}, 63 \mathrm{~m}, \mathrm{MNHN}$,

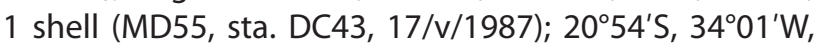
$60 \mathrm{~m}, \mathrm{MNHN}, 2$ shells (MD55, sta. DC42, 17/v/1987).

Additional (non-MD55) material: Caribbean; Bahamas: Grand Bahama Island, Sandy Beran's Cay, Dead Man's Reef, at the beach, $26^{\circ} 34^{\prime} 45^{\prime \prime} \mathrm{N}, 78^{\circ} 51^{\prime} 45^{\prime \prime} \mathrm{W}$, ANSP 371127, 43 shells (J. Worsfold col.).

Measurements ( \pm standard deviation, in $\mathrm{mm} ; \mathrm{n}=14$ ): $W=1.59 \pm 0.18 ; H=3.61 \pm 0.46 ; w=0.62 \pm 0.14 ;$ $\mathrm{h}=1.03 \pm 0.16$.

Remarks: Conchologically, the MD55 specimens are virtually identical to their Caribbean counterparts, even considering a wide variation in color, outline and sculpture. In specimens from both locations, the ground color is variable from homogeneously white (Figs. 5,6$)$ to white and orange (Figs. 1, 2), with a range of intermediary morphotypes. Shells are invariably turriform, with convex whorls sculptured by thin, closely-spaced spiral cords. The most prominent spiral cord forms a distinct keel on each whorl. This peripheral keel may be somewhat smooth, with wide nodules more easily distinguished in apical view, or bear well-marked angular knobs (Figs. 3, 4). The new records presented herein are distant from the currently known distribution, expanding the range of the species from the Caribbean to the Southwestern Atlantic.

\section{Genus Cerithium Bruguière, 1789}

Type species: Cerithium adansonii Bruguière, 1792, by subsequent designation (Stewart, 1926) (=C. nodulosum Bruguière, 1789) (Sohl, 1960); Recent, Indo-Pacific. 


\section{Cerithium atratum (Born, 1778)}

(Figs. 7-9)

Synonymy see Houbrick (1974), Leal (1991) and Simone (2001). Complement:

Cerithiumatratum:Matthews \& Rios, 1967:68; Furtado-Ogawa, 1970: 195; Oliveira, 1971: 84; Castro \& Santos, 1989: 102; Migotto et al., 1993: 15; Diaz \& Puyana, 1994: 144, pl. 45, fig. 502; Capelo \& Buitrago, 1998: 123; Gordillo, 1998: 166; Salvador et al., 1998: 1015, fig.4; Bitter \& Martinez, 2001:29; Arruda\&Amaral, 2003:297; Sevilla etal., 2003:318;Denadai et al., 2004: 1696; Boehs et al., 2004: 539; Bandel, 2006: 114, pl. 1, fig. 2; Rosenberg et al., 2009: 627; Amaral et al,, 2010: 235, fig. 18; Souza et al., 2010: 367; Gernet \& Birckolz, 2011: 44; Gondim et al., 2011: 78; Matthews-Cascon et al., 2011: 25, pl. 3, figs. A-C; Ourives et al., 2011: 330; Strong et al., 2011: 50, fig. 1F; Barroso et al., 2013: 507, pl. 2, fig. 32; Petuch, 2013: 26, fig. 2.9A; Aguilar-Estrada et al., 2014: 508; Longo et al., 2014: 3, fig. 2A.

Cerithium (Thericium) atratum: Redfern, 2001: 20, pl. 11, fig. 82; Rios, 2009: 107, text fig.

Type locality: Guadeloupe (subsequent designation by Houbrick, 1974).

Distribution: Amphi-Atlantic; Eastern Atlantic: Mauritania to southern Angola; Western Atlantic: North Carolina, USA to Santa Catarina, Brazil (for details see Houbrick, 1974: 61, pl. 29; Simone, 2001).

Material examined: Brazil; off Espírito Santo: Jaseur Seamount, $20^{\circ} 27^{\prime} \mathrm{S}, 35^{\circ} 54^{\prime} \mathrm{W}, 54 \mathrm{~m}, \mathrm{MNHN}, 1$ shell + fragments (MD55, sta. DC34; 15/v/1987).

Additional (non-MD55) material: Brazil; Espírito Santo: Aracruz, Praia do Coqueiral, MZSP 91259, 2 shells (L.R.L. Simone col., ii/1998); Guarapari, MZSP 52940, 30 spms (Montouchet col., 06/xii/1968).

Measurements (in $\mathrm{mm}$ ): $\mathrm{W}=1.46 ; \mathrm{H}=3.08 ; \mathrm{w}=0.84$; $\mathrm{h}=1.26$.

Remarks: Although the MD55 specimens are juvenile and fragmentary shells, they compare well with the earliest whorls of adult specimens from Espírito Santo (MZSP 91259). Redfern (2001: pl. 11, fig. 82) illustrated a very similar individual from Caribbean (compare with Fig. 7). Leal (1991) had previously reported the occurrence of this species in Jaseur Seamount, off Espírito Santo, Brazil.

\section{Genus Bayericerithium Petuch, 2001}

Type species: Bayericerithium bayeri Petuch, 2001, by original designation; Recent, Brazil.

\section{Bayericerithium bayeri Petuch, 2001} (Figs. 10-12)

Bayericerithium bayeri Petuch, 2001: 336, fig. 1A-C; 2013: 147, fig. 10.2C.
Type locality: Brazil, Pernambuco State, off Gaibu, on muddy sand bottom, $2 \mathrm{~m}$ depth near coralline algal reef.

Distribution: Brazil, state of Pernambuco, $2 \mathrm{~m}$ depth (Petuch, 2001).

New occurrences: Brazil: Ceará, Rio Grande do Norte, Bahia and Espírito Santo states, at 18-120 m depths.

Material examined: Brazil; off Espírito Santo: continental slope of Abrolhos, $18^{\circ} 50^{\prime} \mathrm{S}, 37^{\circ} 57^{\prime} \mathrm{W}, 60 \mathrm{~m}$, 4 shells, MZSP 105301, 2 shells (MD55, sta. DC83, 28/v/1987); $18^{\circ} 59^{\prime} \mathrm{S}, 37^{\circ} 48^{\prime} \mathrm{W}, 607-620 \mathrm{~m}, \mathrm{MNHN}, 1$ shell, (MD55, sta. DC73, 27/v/1987); Jaseur Seamount, $20^{\circ} 27^{\prime} \mathrm{S}$, $35^{\circ} 54^{\prime} \mathrm{W}, 54 \mathrm{~m}, \mathrm{MNHN}, 2$ shells (sta. DC34; 15/v/1987).

Additional (non-MD55) material: Brazil; Ceará: off Fortaleza, 18 m depth, MZSP 33517, 1 shell (H.R. Matthews col., VI/1967; former H.R. Matthews collection, № 491). Rio Grande do Norte: off Touros, Praia do Cajueiro, 18-21 m, MZSP 100667, 2 shells (col. by diving, 2011; under rocks); off Rio do Fogo, 20-25 m, MZSP 67938, 1 shell (A. Bodart col., III/1999; in coral sand), MZSP 70225, 3 shells (A. Bodart col., III/1999; in coral sand), 10-15 m, MZSP 74554, 38 shells (M. Coltro col., I/2007). Bahia: Minerva Seamount, $17^{\circ} 01^{\prime} \mathrm{S}, 37^{\circ} 37^{\prime} \mathrm{W}$, $50 \mathrm{~m}$, MZSP 107939, 5 spm (dredged, J. Coltro col., 12/ $\mathrm{VIII} / 2012), 17^{\circ} 06^{\prime} \mathrm{S}, 37^{\circ} 38^{\prime} \mathrm{W}, 120 \mathrm{~m}, \mathrm{MZSP} 110859$, 15 spm (dredged, local fishermen col., VIII/2012), MZSP 110910, 66 shells (dredged, local fishermen col., VIII/2012), MZSP 110959, 20 spm (dredged, local fishermen col., VIII/2012); off Alcobaça, 5-10 m, MZSP 33188, 8 spm (A. Bodart col., VII/2001), MZSP 34065, 21 spm (A. Bodart col., VII/2001), MZSP 65240, 10-12 m, 2 shells (A. Bodart col., VII/2001), MZSP 65241, 2 shells (A. Bodart col., 1/2005; in coral sand), MZSP 69418, 15 spm (A. Bodart col., I/2005; in coral sand), 20-25 m, MZSP 69417, 1 spm (A. Bodart col., 1/2005; in coral sand), MZSP 71941, 1 shell (A. Bodart col., IX/2001; in coral sand), MZSP 72318, 24 shells (A. Bodart col., VI/2001; in coral sand), Escalada Reef, 5-10 m, MZSP 34545, 2 spm (A. Bodart col., 1/2002); unknown locality off southern Bahia, MZSP 35897, 4 shells (local fishermen col., 2002). Espírito Santo: off Guarapari, MZSP 91069, 6 spm (J. Coltro col., 2009).

Measurements ( \pm standard deviation, in $\mathrm{mm} ; \mathrm{n}=9$ ): $W=2.32 \pm 0.91 ; \mathrm{H}=4.01 \pm 1.49$.

Remarks: Although all the MD55 specimens are juvenile empty shells (Figs. 11-12), they compare exceedingly well with the earliest whorls of well-preserved adult specimens from relatively close locations. Adult B. bayeri have thick, stubby shells, but the initial spire whorls have a straight conical outline in some specimens (Petuch, 2001: fig. 1A-C). Ground color is cream-white, with widely spaced orange bands arranged in a zebra-like pattern, as reported by Petuch (2001) in the original description. In the present specimens, these colors are sometimes mixed with a diffuse violet-pinkish shade, especially in the initial 2-3 teleoconch whorls. The MD55 specimens 
also have poorly developed sculpture except for very faint subsutural knobs and numerous densely packed spiral threads, which compares well with the original description. The distribution of $B$. bayeri was originally restricted to Pernambuco, but it is herein greatly expanded ca. $510 \mathrm{~km}$ northward to Rio Grande do Norte and Ceará states, and ca. 1,350 km southward to the states of Bahia and Espírito Santo. Petuch (2013) considered B. bayeri endemic to the Cearaian Biogeographic Subprovince (sensu Petuch, 2013), but the records reported herein are evidence of a wider range. In this sense, the species also occurs in the author's neighbor Bahian Province (from Alagoas to Rio de Janeiro states). The species' bathymetric range is also expanded as live specimens were collected at depths of up to $120 \mathrm{~m}$ (the only deeper record consists of empty shells, which were probably carried). Bayericerithium has been recently listed as a synonym of Cerithium in online taxonomic databases (e.g., Rosenberg, 2009, 2014), which also list Cerithium bayeri (Petuch, 2001) as the valid combination. However, there is a Cerithium bayeri Beets, 1941, a fossil species from the Miocene of Indonesia (Beets, 1981). This would make C. bayeri (Petuch, 2001) a junior secondary homonym according to the ICZN (Art. 57.3). In the light of these facts, and since no formal revision including Bayericerithium has been published so far, we have chosen to keep the original combination.

\section{Family Litiopidae Genus Alaba H. \& A. Adams, 1853}

Type species: Rissoa melanura C.B. Adams, 1850, by subsequent designation [= Alaba incerta (d'Orbigny)]; Recent, Atlantic.

\section{Alaba incerta (d'Orbigny, 1841)}

(Figs. 13-16)

Synonymy see Leal (1991) and Simone (2001). Complement:

Alaba incerta: Absalão, 1989: 3; Redfern, 2001: 22, pl. 12, fig. 91A-B; Sevilla et al., 2003: 319; Rivera \& Navarrete, 2007: 155, fig. F; Rios, 2009: 109 text fig.; Ourives et al., 2011: 330; Strong et al., 2011: 51; Longo et al., 2014: 4, fig. $3 \mathrm{~J}$.

Type locality: Jamaica.

Material examined: Brazil, Rio de Janeiro, off Salinas, $21^{\circ} 32^{\prime} \mathrm{S}, 40^{\circ} 09^{\prime} \mathrm{W}, 295-300 \mathrm{~m}, 2$ shells (1 juvenile; MD55, sta. CB96; 31/v/1987).

Distribution: From Gulf of Mexico to Brazil (Rios, 2009; Miloslavich et al., 2010).

Measurements (in $\mathrm{mm}$; illustrated specimen): $\mathrm{W}=1.41$; $\mathrm{H}=3.8 ; \mathrm{w}=0.66 ; \mathrm{h}=1.08$.

Remarks: Though none of the specimens studied herein were collected alive, the present records represent a bathy- metric expansion from the previously reported range (of 0-40 m; Rosenberg, 2009), going as deep as $300 \mathrm{~m}$.

\section{Genus Litiopa Rang, 1829}

Type species: Litiopa melanostoma Rang, 1829, by original designation; Recent, Atlantic.

\section{Litiopa melanostoma Rang, 1829 \\ (Figs. 17-20)}

Synonymy see Watson (1886), Tryon-Jr. (1887), Palmer (1942), Houbrick (1987a) and Bouchet (2002). Complement:

Bombyxinus uva Bélanger in Lesson, 1831: sign. 14.

Litiopa melanostoma: Lebour, 1945: 462, fig. 8A-D; Morretes, 1949: 79, Abbott, 1954: 156, pl. 21, fig. k; Parker \& Curray, 1956: 2434, tab.; Warmke \& Abbott, 1962: 74, pl. 13, fig. G; Rios, 1970: 43, 1975: 50, pl. 13, 1985: 52, pl. 19, 1994: 63, pl. 21, 2009: 108, text fig.; Robertson, 1971:4; Abbott, 1974: 108, fig. 1047; Stoner \& Greening, 1984: 187, tab. 2; Houbrick, 1987a: 9; Jong \& Coomans, 1988: 45, pl. 15; Scheltema et al., 1989: 139; Avila et al., 1998: 497; Redfern, 2001: 22, pl. 12, fig. 90A-B; Scarabino, 2004: 275; Reyes et al., 2007: 383, tab. 01; Williams et al., 2008: 67; Prozorova et al., 2012: 167; Huffard et al., 2014: 2741.

Type locality: Originally referred to as "mers de TerreNeuve", which corresponds to the seas of Newfoundland, eastern Canada, according to Higo et al. (1999).

Distribution: Worldwide in open seas (Higo et al., 1999); Western Atlantic, from Gulf of Mexico to Venezuela (Miloslavich et al., 2010) and Brazil (Rios, 2009); Eastern Atlantic, from Azores to European waters (Avila et al., 1998); Pacific, tropical latitudes (Gofas et al., 2001).

Material examined: Brazil; off Espírito Santo: Abrolhos Continental Slope, $18^{\circ} 58^{\prime} \mathrm{S}, 37^{\circ} 48^{\prime} \mathrm{W}, 682 \mathrm{~m}, \mathrm{MNHN}$, 2 shells (MD55, sta. SY74, 27/v/1987); $18^{\circ} 59^{\prime}$ S, 37048' W, 1,540-1,550 m, MNHN, 3 shells, MZSP 147433, 2 shells (MD55, sta. DC70, 26/v/1987); 1900'S, 3749'W, 950-1,050 m, MNHN, 3 shells, MZSP 147434, 2 shells (MD55, sta. DC72, 27/v/1987).

Measurements ( \pm standard deviation, in $\mathrm{mm} ; \mathrm{n}=12$ ): $\mathrm{H}=3.33 \pm 0.73 ; \mathrm{W}=1.57 \pm 0.23 ; \mathrm{h}=1.39 \pm 0.22$; $\mathrm{w}=0.71 \pm 0.18$

Remarks: Though none of the specimens studied herein were collected alive (Fig. 19), the present records of well-preserved specimens represent a bathymetric expansion from the previously reported range of 0-805 m (Rosenberg, 2009), going as deep as 1,540-1,550 m. Nevertheless, this is a pelagic species that lives attached to floating debris (Higo et al., 1999). The present material was probably carried by debris floating at the surface level to the localities reported herein, and the shells sunk after death. 


\section{Family Modulidae \\ Genus Modulus Potiez \& Michaud, 1838}

Type species: Trochus modulus Linnaeus, 1758 by subsequent designation (Gray, 1847). Recent, Atlantic.

\section{Modulus modulus (Linnaeus, 1758)}

(Figs. 21-23)

Synonymy see Abbott (1944), Leal (1991) and Simone (2001). Complement:

Modulus modulus: Matthews \& Rios, 1967: 68; Macsotay \& Campos, 2001: 45; Rios, 2009: 106, text fig.; Rosenberg et al., 2009: 627; Strong et al., 2011: 51, fig. 1H; Longo et al., 2014: 5, fig. $5 \mathrm{G}$.

Modulus carchedonius: Absalão, 1989: 2; Rios, 2009: 106, text fig. (non Lamarck, 1822).

Distribution: Western Atlantic, from Florida to Santa Catarina, Brazil (Simone, 2001).

Material examined: Brazil; off Espírito Santo: Abrolhos Continental Slope, $18^{\circ} 56^{\prime} \mathrm{S}, 37^{\circ} 52^{\prime} \mathrm{W}, 85-105 \mathrm{~m}, \mathrm{MNHN}$, 2 shells, MZSP 147435, 1 shell (MD55, sta. DC82, 28/v/1987); $18^{\circ} 50^{\prime} \mathrm{S}, 37^{\circ} 57^{\prime} \mathrm{W}, 60 \mathrm{~m}, \mathrm{MNHN}, 2$ shells (MD55, sta. DC83, 28/v/1987).

Measurements ( \pm standard deviation, in $\mathrm{mm}$ ): $\mathrm{W}=3.29 \pm 0.55 ; \mathrm{H}=3.4 \pm 0.43$.

Remarks: Leal (1991) reported the occurrence of $M$. modulus in Vitória, Montague, Jaseur, Davis and Dogaressa Seamounts, but did not mention the Abrolhos Slope. This species lives at intertidal and upper infratidal levels (Abbott, 1944; Simone, 2001). The presence of samples in the given depths is possibly due to post mortem dislodging, even though there are records as deep as $105 \mathrm{~m}$ (Rosenberg et al., 2009).

\section{Family Planaxidae \\ Subfamily Planaxinae Gray, 1850 \\ Genus Angiola Dall, 1926}

Type species: Angiola periscelida Dall, 1926 by original designation. Recent, Pacific.

\section{Angiola lineata (Costa, 1778) (Figs. 24-27)}

Synonymy see Houbrick (1987b) and Leal (1991). Complement:

Angiola lineata: Cruz \& Gándara, 2006: 130; Rodríguez \& Campos, 2013: 109; Capote et al., 2014: 20.

Distribution: Western Atlantic, from Bermuda and Florida to northern South America; Brazil, restricted to Trindade and Martin Vaz Islands; S/E Atlantic, Oceanic Islands of Ascension, Santa Helena, Canary Islands and Cape Verde (Leal, 1991).
Material examined: Brazil, Espírito Santo, off Conceição da Barra, Abrolhos Continental Slope, $18^{\circ} 59^{\prime} \mathrm{S}, 37^{\circ} 50^{\prime} \mathrm{W}$, 637 m, 1 shell (MD55, sta. CB76; 27/v/1987).

Measurements (in $\mathrm{mm}$ ): $\mathrm{W}=2.15 ; \mathrm{H}=3.53 ; \mathrm{w}=0.9$; $\mathrm{h}=1.52$.

Remarks: Leal (1991) reported the occurrence of $A$. lineata in the Islands of Trindade and Martin Vaz, but did not mention the Abrolhos Slope, which is located ca. $870 \mathrm{~km}$ to the west. The present record thus represents a considerable range expansion.

\section{Subfamily Fossarinae Adams, 1860 Genus Fossarus Philippi, 1841}

Type species: Fossarus adansoni Philippi, 1841, by monotypy [= Fossarus ambiguus (Linnaeus, 1758)]; Recent, Mediterranean.

\section{Fossarus orbignyi Fischer, 1864}

(Figs. 28-29)

Synonymy see Leal (1991). Complement:

Fossarus orbignyi: Matthews \& Rios, 1974: 49; Houbrick, 1990: 61; Rosenberg et al., 2009: 627.

Fossarus orbignyi Fischer, 1854 [sic]: Absalão, 1989: 3; Rios, 1994: 54, pl. 21, fig. 245, 2009: 111, text fig.

Fossarus ambiguus: Longo et al., 2014: 5, fig. 5J (non Linnaeus, 1758).

Type locality: Cuba, Guadeloupe, Saint Lucia, Jamaica.

Distribution: from Bermuda to Santa Catarina, Brazil, including oceanic islands Atol das Rocas, Fernando de Noronha and Trindade (Leal, 1991).

Material examined: Brazil; off Espírito Santo: continental slope of Abrolhos, 18 $59^{\prime} \mathrm{S}, 37^{\circ} 50^{\prime} \mathrm{W}, 295 \mathrm{~m}, \mathrm{MNHN}$, 1 shell (MD55, sta. DC75, 27/v/1987); off Rio de Janeiro: S of Cabo Frio, $23^{\circ} 54^{\prime} \mathrm{S}, 42^{\circ} 10^{\prime} \mathrm{W}, 830 \mathrm{~m}, \mathrm{MNHN}, 1$ juvenile shell, MZSP 147436, same (MD55, sta. CB106, 02/vi/1987).

Measurements (in $\mathrm{mm}$ ): $\mathrm{W}=1.81 ; \mathrm{H}=2.08 ; \mathrm{w}=0.8$; $h=1.2$.

Remarks: The present records represent a bathymetric expansion from the previously reported range (of 0-40 m; Rosenberg, 2009), going as deep as $830 \mathrm{~m}$. Despite being well-preserved, the present specimens are empty shells and could have been dislodged after death.

\section{DISCUSSION}

Despite the absence of new species in the present assembly, the numerous range and bathymetric range expansions reported herein are a relevant step towards a better understanding of the Brazilian seamount and deep-water environments. Some of the species reported 


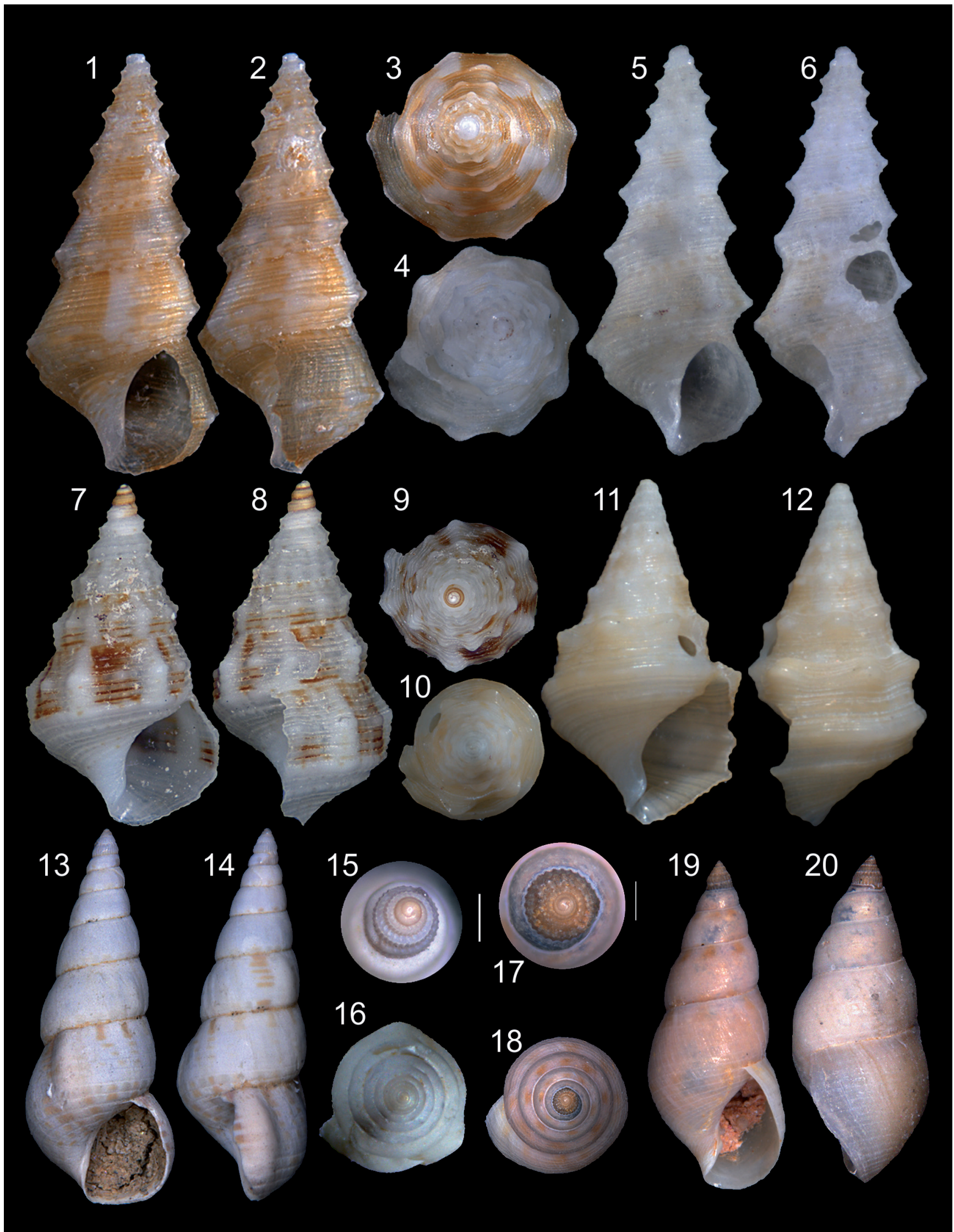

Figures 1-20. Cerithiidae and Litiopidae collected by the MD55 expedition off SE Brazil; (1-6) Ittibittium oryza; (1-3) MZSP 122161, sta. DC22 (L 4.5 mm), (1) apertural, (2) right lateral and (3) apical views; (4-6) MNHN, sta. DC35 (L $3.8 \mathrm{~mm})$, (4) apical, (5) apertural and (6) right lateral views; (7-9) Cerithium atratum, MNHN, sta. DC34 (L $3.2 \mathrm{~mm}$ ), (7) apertural, (8) right lateral and (9) apical views; (10-12) Bayercerithium bayeri juvenile specimen, MNHN, sta. DC34 (L 2.5 mm), (10) apical, (11) apertural, and (12) right lateral views; (13-15) Alaba incerta MNHN, sta. CB96 (L $3.8 \mathrm{~mm}),(13)$ apertural view, (14) right lateral, (15) protoconch detail, (16) apical view (scale $=0.2 \mathrm{~mm})$. (17-20) Litiopa melanostoma MNHN, sta. DC72 (L $4.5 \mathrm{~mm})$, (17) protoconch detail (scale = $0.2 \mathrm{~mm}),(18)$ apical, (19) apertural, (20) right lateral views. 


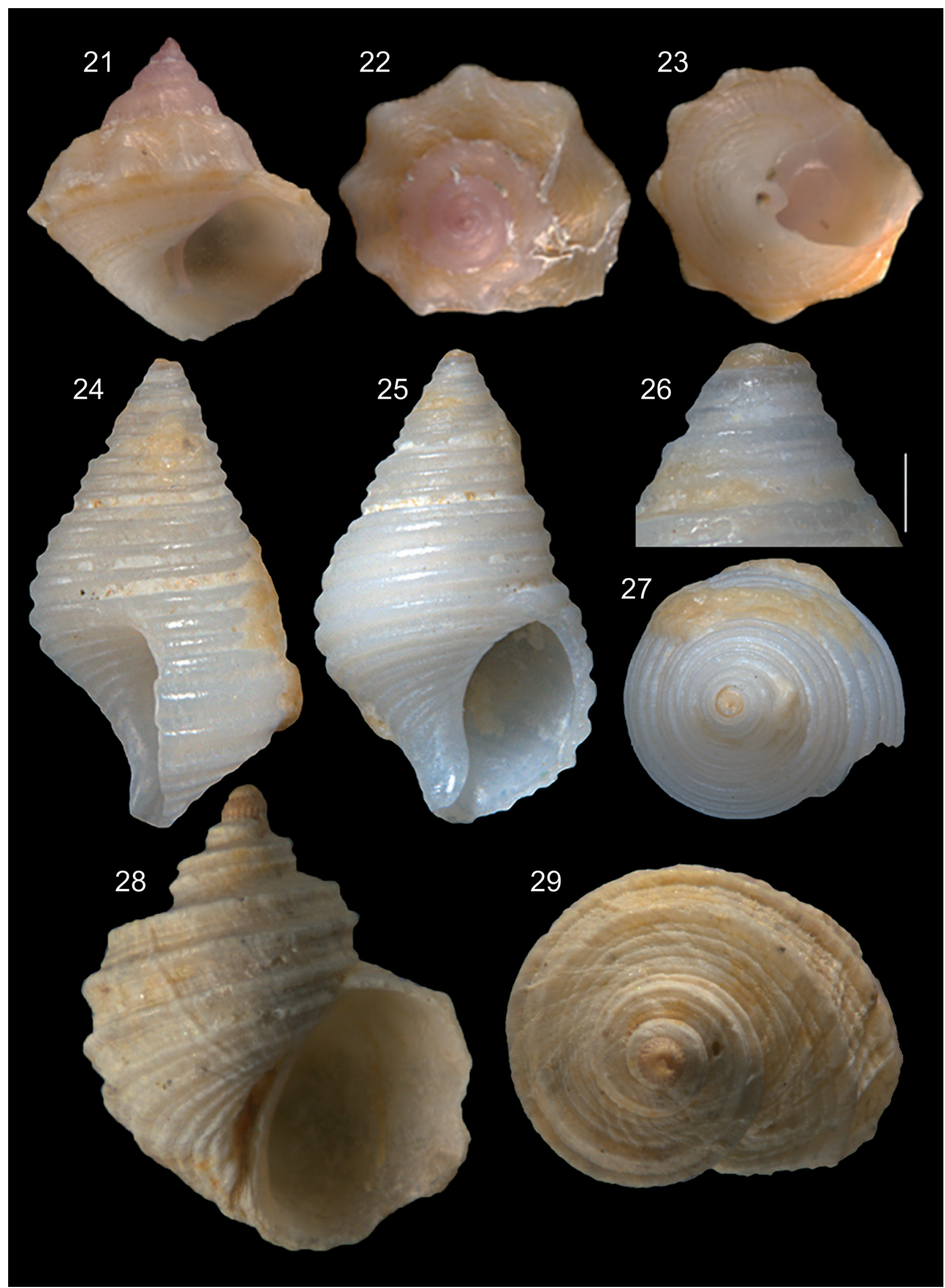

Figures 21-29. Modulidae and Planaxidae collected by the MD55 expedition off SE Brazil; (21-23) Modulus modulus MNHN, sta. DC83 (W 4 mm), (21) apertural, (22) apical and (23) umbilical views; (24-27) Angiola lineata, MNHN, sta. CB76 (L $3.5 \mathrm{~mm})$, (24) right lateral and (25) apertural views, (26) detail of apex (scale = $0.2 \mathrm{~mm}),(27)$ apical view; (28-29) Fossarus orbigny, MNHN, sta. DC75 (W 2.08 mm), (28) apertural and (29) apical views. 
herein are known to live attached to floating debris and algae (e.g., Alaba incerta, Litiopa melanostoma; Higo et al., 1999) and were most likely carried to the collection localities along with their respective floating substrates, sinking after death. The deepest records for these species reported in the literature, including the ones presented herein, consist of empty shells. On the other hand, some of the remaining species found in the present samples can live in deeper waters, especially Bayericerithium bayeri (1-120 m) and Modulus modulus (1-105 m) (Rosenberg et al., 2009). Unfortunately, the specimens had no soft parts, which prevents further analysis.

One of the species studied herein, Ittibittium oryza, is reported from the southwestern Atlantic for the first time. This is not unprecedent, since several papers based totally or partially on MD55 material reported the presence of genera and species of gastropods previously unrecorded in the Southwestern Atlantic (e.g., Fernandes et al., 2013; Simone \& Cunha, 2014; Salvador et al., 2014; Cavallari et al., 2019; Fernandes \& Pimenta, 2020). Significant range expansions of over $1,000 \mathrm{~km}$ have also been frequently reported in these studies (e.g., Cavallari et al., 2014; Salvador et al., 2014; Simone \& Cunha, 2014; Cavallari et al., 2019). In many cases, the new records leave large occurrence gaps (e.g., some species recorded in the Caribbean and off southeastern Brazil, as in I. ory$z a)$. Actually, this may not reflect a real absence of occurrence, but rather an absence of samplings and studies (Fernandes \& Pimenta, 2020), which reinforces the importance of the present and other similar efforts.

Bringing information about the Brazilian deep-water fauna into light has become an urgent task in face of the potential biodiversity loss due to oil extraction activities that are currently being or will be carried out in the country (Meira et al., 2016; Francini-Filho et al., 2018). Some of the extraction areas are or may be within the region sampled in MD55 expedition (Romero et al., 2011), which makes the matter even more critical. The MD55 material is a partial portrait of the deep-sea fauna of southeastern Brazil from over 30 years ago. The changes that this fauna could have undergone since then, and what could be the impacts caused by the oil extraction activities are important questions, which should be addressed in future studies.

\section{ACKNOWLEDGEMENTS}

We are deeply grateful to Philippe Bouchet (MNHN) for the invitation to study the MD55 material; to José Coltro Jr. (Femorale) for providing the trip to Paris for L.R.L.S.; to Philippe Maestrati and Virginie Héros (MNHN) for their kind help and hospitality, and to Vinicius Padula (MNRJ) and an anonymous referee for their careful, constructive and thorough revision of the manuscript.

\section{REFERENCES}

Abbott, R.T. 1944. The genus Modulus in the Western Atlantic. Johnsonia, 1(14): 1-6.
Abbott, R.T. 1954. American Seashells. New York, Van Nostrand C0. 541p.

Abbott, R.T. 1974. American Seashells: The Marine Molluska of the Atlantic and Pacific Coasts of North America, $2^{\text {nd }}$ ed. New York: Van Nostrand Co., $663 \mathrm{pp}$.

Absalão, R.S. 1989. Padrões distributivos e zoogeografia dos moluscos da plataforma continental brasileira. Parte III. Comissão Oceanográfica Espírito Santo I. Memórias do Instituto Oswaldo Cruz, 84(suppl. 4): 1-6.

Aguilar-Estrada, L.G.; Ortigosa, D.; Urbano, B. \& Reguero, M. 2014. Análisis histórico de los gasterópodos de la laguna arrecifal de Isla Verde, Veracruz, México. Revista Mexicana de Biodiversidad, 85: 502-512.

Amaral, A.C.Z.; Migotto, A.E.; Turra, A. \& Schaeffer-Novelli, Y. 2010. Araçá: biodiversidade, impactos e ameaças. Biota Neotropica, 10(1): 219-264.

Arruda, E.P. \& Amaral, A.C.Z. 2003. Spatial distribution of mollusks in the intertidal zone of sheltered beaches in southeastern of Brazil. Revista Brasileira de Zoologia, 20(2): 291-300.

Avila, S.P.; Azevedo, J.M.N.; Gonçalves, J.M.; Fontes, J. \& Cardigos, F. 1998. Checklist of the shallow-water marine molluscks of the Azores: Pico, Faial, Flores and Corvo. Açoreana, 8(4): 487-523.

Bandel, K. 2006. Families of the Cerithioidea and related superfamilies (Palaeo-Caenogastropoda; Mollusca) from the Triassic to the Recent characterized by protoconch morphology - including the description of new taxa. Freiberger Forschungshefte, 511(14): 59-138.

Barroso, C.X.; Rabay, S.G.; Meirelles, C.A.O. \& Matthews-Cascon, H. 2013. Mollusks from two estuarine areas in Ceará State, northeastern Brazil, with new state records for four species. Check List, 9(3): 504-509.

Beesley, L.P.; Ross, G.J.B. \& Wells, A. (Eds.). 1998. Mollusca: the Southern Synthesis. Part B. Melbourne, CSIRO Publishing. p. 564-1234.

Beets, C. 1981. Note on Mollusca from the Lower Mentawir Beds, Balikpapan Bay area, Kalimantan (East Borneo). Scripta Geologica, 59: 1-12.

Bitter, R.S. \& Martinez, R.E. 2001. Inventario de los moluscos marinos en las costas del Estado Falcon, Venezuela. Acta Biologica Venezuelica, 21(1): 21-41.

Boehs, G.; Absher, T.M. \& Cruz-Kaled, A. 2004. Composition and distribution of benthic molluscs on intertidal flats of Paranaguá Bay (Paraná, Brazil). Scientia Marina, 68(4): 537-543.

Bouchet, P. 2002. Gone with the wind: a pelagic marine snail described as an endemic land snail from the Bahamas. Nautilus, 116(1): 32-35.

Capelo, J.C. \& Buitrago, J. 1998. Distribución geográfica de los moluscos marinos en el oriente de Venezuela. Memoria de La Sociedad de Ciencias Naturales La Salle, 58(150): 109-160.

Capote, A.J.; García, Y.L.D. \& Tamayo, D.T. 2014. Composición de los moluscos de la zona fital del mesolitoral del rocoso en Santiago de Cuba. Amici Molluscarum, 22(1): 15-27.

Castro, G.A. \& Santos, E.F. 1989. Levantamento preliminar de moluscos em praias arenosas e areno-lodosas de Piúma, estado do Espírito Santo, Brasil. Memórias do Instituto Oswaldo Cruz, 84(suppl. 4): 101-104.

Cavallari, D.C.; Salvador, R.B. \& Simone, L.R.L. 2014. Taxonomical study on the Architectonicidae collected by the Marion Dufresne (MD55) expedition to SE Brazil (Gastropoda, Heterobranchia). Spixiana, 37(1): 35-43.

Cavallari, D.C.; Salvador, R.B.; Dornellas, A.P.S. \& Simone, L.R.L. 2019. Calliostomatidae, Colloniidae, Margaritidae, and Solariellidae (Gastropoda: Trochoidea) collected by the Marion Dufresne (MD55) expedition in southeastern Brazil, with description of a new species of Calliostoma. Zootaxa, 4609(3): 401-428.

Cruz, F.V. \& Gándara, C.G. 2006. Lista actualizada de los gasterópodos de la planicie del Arrecife Lobos, Veracruz, Mexico. Revista UDO Agricola, 6(1): 128-137.

Denadai, M.R.; Amaral, A.C.Z. \& Turra, A. 2004. Biology of a tropical intertidal population of Cerithium atratum (Born, 1778) (Mollusca, Gastropoda). Journal of Natural History, 38(13): 1695-1710. 
Diaz, J.M.M. \& Puyana, M.H. 1994. Moluscos Del Caribe Colombiano. Bogota, Colciencias Fundación Natura. 291p.

Faber, M.J. 2005. The Caribbean marine gastropods described by 0tto Andreas Lawson Mørch. 1: some type specimens and identifications (Gastropoda: Prosobranchia). Miscellanea Malacologica, 1(5): 81-99.

Fernandes, M.R. \& Pimenta, A.D. 2020. Unraveling one of the 'Big Five': update of the taxonomy of Triphoridae (Gastropoda, Triphoroidea) from Brazil. European Journal of Taxonomy, 665: 1-170.

Fernandes, M.R.; Pimenta, A.D. \& Leal, J.H. 2013. Taxonomic review of Triphorinae (Gastropoda: Triphoridae) from the Vitoria-Trindade Seamount Chain, southeastern Brazil. Nautilus, 127: 1-18.

Francini-Filho, R.B.; Asp, N.E.; Siegle, E.; Hocevar, J.; Lowyck, K.; D'Avila, N.; Vasconcelos, A.A.; Baitelo, R.; Rezende, C.E.; Omachi, C.Y.; Thompson, C.C. \& Thompson, F.L. 2018. Perspectives on the Great Amazon Reef: Extension, Biodiversity, and Threats. Frontiers in Marine Science, 5(142). D0I

Furtado-0gawa, E. 1970. Contribuição ao conhecimento da fauna malacológica intertidal de substratos duros do Nordeste brasileiro. Arquivos de Ciências do Mar, 10(2): 193-196.

Gernet, M.V. \& Birckolz, C.J. 2011. Fauna malacológica em dois sambaquis do litoral do Estado do Paraná, Brasil. Biotemas, 24(3): 39-49.

Gofas, S.; Le Renard, J. \& Bouchet, P. 2001. Mollusca. Collection Patrimoines Naturels, 50: 180-213.

Gondim, A.l; Dias, T.L.P.; Campos, F.F.; Alonso, C. \& Christoffersen, M.L. 2011. Macrofauna bêntica do Parque Estadual Marinho de Areia Vermelha, Cabedelo, Paraíba, Brasil. Biota Neotropica, 11(2): 75-86.

Gordillo, S. 1998. Distribuición biogeográfica de los moluscos holocenos del litoral Argentino-Uruguaio. Ameghiniana, 35(2): 163-180.

Gray, M.E. 1847. A list of the genera of recent Mollusca, their synonyma and types. Proceedings of the Zoological Society of London, 15: 129-219.

Higo, S.; Callomon, P. \& Goto, Y. 1999. Catalogue and Bibliography of the Marine Shell-bearing Mollusca of Japan: Gastropoda, Bivalvia, Polyplacophora, Scaphopoda. Japan, Elle Scientific Publications. 749p.; 2 maps.

Houbrick, R.S. 1974. The genus Cerithium in the Western Atlantic. Johnsonia, 5(50): 33-84.

Houbrick, R.S. 1980. Observations on the anatomy and life history of Modulus modulus (Prosobranchia: Modulidae). Malacologia, 20(1): 117-142.

Houbrick, R.S. 1987a. Anatomy of Alaba and Litiopa (Prosobranchia: Litiopidae): Systematic implications. Nautilus, 101(1): 9-18.

Houbrick, R.S. 1987b. The Anatomy, Reproductive Biology, and Phylogeny of the Planaxidae (Cerithiacea: Prosobranchia). Smithsonian Contributions to Zoology, 445: 1-57.

Houbrick, R.S. 1990. Anatomy, reproductive biology and systematic position of Fossarus ambiguus (Linné) (Fossarinae: Planaxidae; Prosobranchia). Açoreana, (Suppl.): 59-73.

Huffard, C.L.; Thun, S.; Sherman, A.D.; Sealey, K. \& Smith Jr, K.L. 2014. Pelagic Sargassum community change over a 40-year period: temporal and spatial variability. Marine Biology, 161(12): 2735-2751.

Jong, K.M. \& Coomans, H.E. 1988. Marine gastropods from Curaçao, Aruba and Bonaire. Leiden, E.J. Brill. 261p.

Leal, J.H. 1991. Marine prosobranch gastropods from oceanic islands off Brazil: Species composition and biogeography. Oegstgeest: Universal Book Services, 419p.

Lebour, M.V. 1945. The Eggs and Larae, of some Prosobranchs from Bermuda. Proceedings of the Zoological Society of London, 114(4): 462-489.

Lesson, R.P. 1831. Illustrations de zoologie, ou, Recueil de figures d'animaux peintes d'après nature. Paris, Arthus Bertrand. 358p.

Longo, P.A.S.; Fernandes, M.C.; Leite, F.P.P. \& Passos, F.D. 2014. Gastropoda (Mollusca) associated to Sargassum sp. beds in São Sebastião Channel São Paulo, Brazil. Biota Neotropica, 14(4): 1-10.
Macsotay, 0. \& Campos, R.A. 2001. Moluscos representativos de la plataforma de Margarita - Venezuela. Descripcion de 24 especies nuevas. Valencia, Rivolta. 280p.

Matthews, H.R. \& Rios, E.C. 1967. Primeira contribuição ao inventário dos moluscos marinhos do Nordeste brasileiro. Arquivos de Ciências do Mar, 7(1): 67-77.

Matthews, H.R. \& Rios, E.C. 1974. Quarta contribuição ao inventário dos moluscos marinhos do Nordeste brasileiro. Arquivos de Ciências do Mar, 14(1): 47-56.

Matthews-Cascon, H; Rocha-Barreira, C.A. \& Meirelles, C.A.O. 2011. Desovas de alguns moluscos brasileiros. Fortaleza, Expressão Gráfica e Editora. $119 \mathrm{p}$.

Meira, R.M.S.A.; Peixoto, A.L.; Coelho, M.A.N.; Ponzo, A.P.L.; Esteves, V.G.L.; Silva, M.C.; Câmara, P.E.A.S. \& Meira-Neto, J.A.A. 2016. Brazil's mining code under attack: giant mining companies impose unprecedented risk to biodiversity. Biodiversity and Conservation, 25: 407-409. D0I

Migotto, A.E.;Tiago, C.G. \& Magalhães, A.R.M. 1993. Malacofauna marinha da região costeira do Canal de São Sebastião, SP, Brasil: Gastropoda, Bivalvia, Polyplacophora e Scaphopoda. Boletim do Instituto Oceanográfico, 41(1-2): 13-27.

Miloslavich, P.; Díaz, J.M.; Klein, E.; Alvarado, J.J.; Díaz, C.; Gobin, J.; Escobar-briones, E.; Cruz-Motta, J.J.; Weil, E.; Cortés, J.; Bastidas, A.C.; Robertson, R.; Zapata, F.; Martín, A.; Castillo, J.; Kazandjian, A. \& Ortiz, M. 2010. Marine Biodiversity in the Caribbean: Regional Estimates and Distribution Patterns. PLOS ONE, 5(8): e11916.

Morretes, F.L. 1949. Ensaio de catálogo dos moluscos do Brasil. Arquivos do Museu Paranaense, 7(1): 5-216.

Oliveira, M.I.M. 1971. Contribuição ao estudo da malacofauna intertidal de recifes de arenito do Nordeste brasileiro. Arquivos de Ciências do Mar, 11(2): 83-86.

Ourives, T.M.S.; Guerrazzi, M.C. \& Simone, L.R.L. 2011. Gastropods from Camamu Bay, state of Bahia, Brazil. Check List, 7(3): 328-336.

Palmer, K.V.W. 1942. Notes on the name Litiopa melanostoma Rang and distribution of the species. Nautilus, 55: 128-130.

Parker, R.H. \& Curray, J.R. 1956. Fauna and bathymetry of banks on continental shelf, northwest Gulf of Mexico. Bulletin of the American Association of Petroleum Geologists, 40(10): 2428-2439.

Petuch, E.J. 2001. New gastropods named for Frederick M. Bayer, in recognition of his contributions to tropical Western Atlantic malacology. Bulletin of the Biological Society of Washington, 10: 334-343.

Petuch, E.J. 2013. Biogeography and biodiversity of Western Atlantic mollusks. Boca Raton, CRC Press. 234p.

Prozorova, L.A.; Sitnikova, T.Ya.; Kashin, I.A. \& Zvyagintsev, A.Yu. 2012. First finding of Diffalaba vitrea (Sowerby III, 1915) (Gastropoda: Litiopidae) in Russian waters of the Sea of Japan (Peter the Great Bay). Bulletin of the Russian Far East Malacological Society, 15-16: 165-169.

Redfern, C. 2001. Bahamian seashells: A thousand species from Abaco, Bahamas. Boca Raton, Bahamianseashells. 280p., 124 pls.

Reyes, J.L.; Sánchez, A.F.; Carruyo-Noguera, J.; Casler, C.L.; Narciso, S.; Nava, M. \& Guerra-Gómez, A. 2007. Moluscos gasterópodos y bivalvos de la Alta Guajira, Estado Zulia, Venezuela. Boletín del Centro de Investigaciones Biologicas, 41(3): 376-393.

Rios, E.C. 1970. Coastal Brazilian seashells. Rio Grande, Fundação Cidade do Rio Grande, Museu Oceanográfico de Rio Grande. 255p 4 maps, 60 pls.

Rios, E.C. 1975. Brazilian marine mollusks iconography. Rio Grande, FURG. 312 p., 91 pls.

Rios, E.C. 1985. Compendium of Brazilian seashells. Rio Grande, FURG. 328p., 101 pls.

Rios, E.C. 1994. Seashells of Brazil. Rio Grande, Universidade do Rio Grande. 368p., 113 pls. 
Rios, E.C. 2009. Compendium of Brazilian seashells. Rio Grande, Evangraf. $668 p$.

Rivera, J.J.0. \& Navarrete, A.J. 2007. Larvas de moluscos gasterópodes del sur de Quintana Roo, México. Hidrobiológica, 17(2): 151-158.

Robertson, R. 1971. Scanning electron microscopy of planktonic larval marine gastropod shells. Veliger, 14: 1-13.

Rodríguez, J.Q. \& Campos, N.H. 2013. Moluscos asociados a ensamblajes macroalgales en el litoral rocoso de Córdoba, Caribe Colombiano. Boletín de Investigaciones Marinas y Costeras, 42(1): 101-120.

Romero, A.F.; Riedel, 0.S.; Milanelli, J.C.C. \& Lammardo, A.C.R. 2011. Mapa da vulnerabilidade ambiental ao óleo - um estudo de caso na Bacia de Santos, Brasil. Revista Brasileira de Cartografia, 63: 315-332.

Rosenberg, G. 2009. Malacolog 4.1.1: A database of Western Atlantic marine Mollusca. World Wide Web electronic publication. http://www. malacolog.org. Access in: 03/09/2014.

Rosenberg, G. 2014. Cerithium bayeri (Petuch, 2001). World register of marine species. World Wide Web electronic publication. http://www. marinespecies.org/aphia.php? $\mathrm{p}=$ taxdetails\&id=473073. Access in: 13/09/2014.

Rosenberg, G.; Moretzsohn, F. \& García, E.F. 2009. Gastropoda (Mollusca) of the Gulf of Mexico. Pp. 579-699. In: Felder, D.L. \& Camp, D.K. [Eds.]. Gulf of Mexico - origins, Waters, and Biota. Biodiversity. Texas, College Station, Texas A\&M University Press. 1312p.

Salvador, L.B.; Domaneschi, 0.; Amaral, A.C.Z.; Morgado, E.H. \& Henriques, S.A. 1998. Malacofauna da região entremarés de praias da llha de São Sebastião (São Paulo, Brasil). Revista Brasileira de Zoologia, 15(4): 1013-1035.

Salvador, R.B.; Cavallari, D.C. \& Simone, L.R.L. 2014. Seguenziidae (Gastropoda: Vetigastropoda) from SE Brazil collected by the Marion Dufresne (MD55) expedition. Zootaxa, 3878(6): 536-550.

Scarabino, F. 2004. Two gastropods associated with floating objects from the uruguayan coast. Comunicaciones de la Sociedad Malacológica del Uruguay, 8(82-83): 275-277.

Scheltema, R.S.; Williams, I.P. \& Tharpe, J. 1989. Differences in spatial distribution of veliger larvae belonging to Litiopa melanostoma and Alaba incerta (Prosobranchia: Litiopidae) in the warm temperate and tropical North Atlantic Ocean. Journal of Molluscan Studies, 55(1): 139-143.

Sevilla, L.R.; Vargas, R. \& Cortés, J. 2003. Biodiversidad marina de Costa Rica: Gastrópodos (Mollusca: Gastropoda) de la costa Caribe. Revista de Biologia Tropical, 51(suppl. 3): 305-399.
Simone, L.R.L. 2001. Phylogenetic analyses of Cerithioidea (Mollusca, (aenogastropoda) based on comparative morphology. Arquivos de Zoologia, 36(2): 147-263.

Simone, L.R.L. 2014. Taxonomical study on the molluscs collected during the Marion-Dufresne expedition (MD55) off SE Brazil: the Naticidae (Mollusca: Caenogastropoda). Zoosystema, 36(3): 563-593.

Simone, L.R.L \& Cunha, C.M. 2014. Taxonomical study on the mollusks collected in Marion-Dufresne (MD55) and other expeditions to SE Brazil: The Fissurellidae (Mollusca, Vetigastropoda). Zootaxa, 3835(4): 437-468.

Sohl, N.F. 1960. Archeogastropoda, Mesogastropoda, and Stratigraphy of the Ripley, Owl Creek, and Prairie Bluff Formations. Geological Survey Professional Paper, 331-A: 1-139.

Souza, R.C.C.L.; Trindade, D.C.; Decco, J.; Lima, T.A. \& Silva, E.P. 2010. Archaeozoology of marine mollusks from Sambaqui da Tarioba, Rio das Ostras, Rio de Janeiro, Brazil. Zoologia, 27(3): 363-371.

Stewart, R.B. 1926. Gabb's California fossil type gastropods. Proceedings of the Philadelphia Academy of Science, 78: 287-447.

Stoner, A.W. \& Greening, H.S. 1984. Geographic variation in the macrofaunal associates of pelagic Sargassum and some biogeographic implications. Marine Ecology Progress Series, 20: 185-192.

Strong, E.E.; Colgan, D.J.; Healy, J.M.; Lydeard, C.; Ponder, W.F. \& Glaubbrecht, M. 2011. Phylogeny of the gastropod superfamily Cerithioidea using morphology and molecules. Zoological Journal of the Linnean Society, 162: 43-89.

Tavares, M.D.S. 1999. The cruise of the Marion Dufresne off the Brazilian coast: account of the scientific results and list of stations. Zoosystema, 21(4): 597-605.

Tryon-Jr., G.W. 1887. Manual of conchology, structural and systematic: with illustrations of the species. ser. 1, v. 9. Philadelphia, Published by the author. 488p.

Warmke, G.L. \& Abbott, R.T. 1962. Caribbean seashells: A guide to the marine mollusks of Puerto Rico and other West Indian Islands, Bermuda and the lower Florida Keys. Livingston, Livingston Pub. C0. 348p.

Watson, R.B. 1886. II-Report on the Scaphopoda and Gasteropoda collected by H.M.S. Challenger during the years 1873-1876. In: Thomson, W.M.J. 1886. Report on the scientific results of the voyage of H.M.S. Challenger during the years 1873-76: under the command of Captain George S. Nares, R.N., F.R.S. and Captain Frank Turle Thomson, R.N., Zoology, v. XV. Edinburgh, Neill.680p.

Williams, A.; Feagin, R. \& Witmer, A. 2008. Environmental impacts of beach raking of Sargassum spp. on Galveston Island, Texas. Shore \& Beach, 76(2): 63-69. 